\title{
HIGH-VOICED DARK LORDS AND BOGGARTS IN DRAG: FEMININE-CODED VILLAINY IN THE HARRY POTTER SERIES
}

ABSTRACT. Representations of villains in fiction tend to make them conspicuous and easily recognisable, and this is even more frequent in children's literature, which speaks to an inexperienced reading audience and is more likely to follow established narrative patterns or rely on less-than-subtle means of characterisation. An important element in the portrayal of villains, in children's and adult literature alike, is their physical appearance, as is the extent to which they (do not) conform to socially accepted ideas about gender and sexuality. The tendency to represent male villains as somehow aberrant in this sense stems from a long history of viewing the female as a monstrosity in itself, and ascribing feminine features to a man as one of the shortest routes to transforming him into an evil character. Using this theoretical framework as its starting point, this paper will take a closer look at the portrayal of Lord Voldemort, the principal villain of the Harry Potter series, and Severus Snape, whose villainy is revealed to be a ruse only at the very end. The analysis will focus on the ways in which the feminine-coding of these two characters amplifies, but also at times complicates, their status as the villains of the story.

KEYWORDS: children's literature; villain; gender; monstrous-feminine; Harry Potter.

\footnotetext{
bojana.vujin@ff.uns.ac.rs

viktorija.krombholc@ff.uns.ac.rs

This paper was submitted on August $25^{\text {th }}, 2019$ and accepted for publication at the meeting of the Editorial Board held on September $16^{\text {th }}, 2019$.
} 


\section{INTRODUCTION: MONSTROUS BODIES, MONSTROUS} WOMEN

The body has always functioned as a site for expressing meanings that go beyond the corporeal - as an outward reflection of character or its flaws, convenient shorthand for the stigmatization of an entire social group, or a powerful symbol for the inscription of hegemonic social forces. To amplify the villainy of Richard III, Shakespeare compounds his existing deformity, a curved spine, with a withered arm and a limp; what is more, he coaches his character's appearance more broadly in terms of general 'deformity', which transcends any one disability - Richard is not merely a hunchback, but "unfinisht" and "scarce half made up", (I, 1, 20-21) - and this establishes him as monstrous, "slander of [his] mother's womb" (I, 3, 233-238). Even though Richard himself cynically uses his disability to justify his unbridled political ambition, his physical monstrosity becomes inseparable from his moral depravity. In this sense, Shakespeare's Richard is transformed from a disabled tyrant into the living embodiment of evil itself - evil personified, made manifest in its horrific, aberrant, unnatural bodily form.

The body thus often serves as an indispensable feature of characterisation in literature: a visible token of one's psychological make-up, social affiliation, lifestyle choices, or previous experiences. Above all, evil tends to be visibly identifiable. As Enrique Cámara Arenas explains, drawing on findings from cognitive psychology, such stereotypical categorisation is "an energy-saving and time-saving mechanism" (Fahraeus \& Yakali Çamoğlu, 2011, p. 11); it allows for quick and straightforward identification of the bad guy in the story. What is more, one of the key elements in the corporeal coding of depravity and evil are sexuality and gender. As noted by film critic Barbara Creed, "[a]ll human societies have a conception of what it is about a woman that is shocking, terrifying, horrific, abject" (Creed, 1986, p. 44), the idea of the monstrous feminine that captures (and serves to alleviate) anxieties concerning sexual difference. Ranging from the universal anthropological motif of the vagina dentata and the various female monsters and monstrous women from classical myth - the serpent-haired Medusa who turns men to stone, the treacherous sirens from the myth of Odysseus, or the assorted murderous mothers who make their children the instruments of their revenge - to the more contemporary examples 
of the Xenomorph queen of the Alien franchise or Stephen King's teen on a murderous prom rampage, these representations ultimately share the same central tenet: Woman as Abomination. ${ }^{3}$

While female sexuality as such is a source of psychosexual dread and an inspiration for the monstrous female in its many manifestations, gender nonconformity and non-heteronormativity have also long been shorthand for evil, in literature and social consciousness alike. Both strictly defined gender norms and compulsory heterosexuality are essential to dominant patriarchal social structures, which is why any deviation in this respect is portrayed as deviance, quite literally evil incarnate, and the long history of legal persecution and social ostracism of queer people testifies to this. Referring to the trope of the homicidal homosexual in particular, Jordan Schildcrout notes that in "most narratives, these moral monsters exist in order to be eradicated, thus affirming the strength of traditional gender roles, heterosexuality, the family, and conservative values" $(2014$, p. 2). Stoker's Dracula is a well-known case in point. His monstrosity is predicated on the fact that he destabilises the established norms of gender and sexuality, or, as Christopher Craft notes, "the gender-based categories of the penetrating and the receptive" (Craft, 1984, p. 109), and this destabilisation is evident both at the level of the Count's appearance and the ambiguous gender position that he occupies. Likewise, as Jonathan Harker awaits the kiss from one of Dracula's daughters "in languorous ecstasy", he can feel "the soft, shivering touch of the lips on the supersensitive skin of [his] throat" (Stoker, 1983, p. 38); the anticipated penetration is both desired and feared as monstrous, both "a demonic inversion of normal gender relations" (Craft, 1984, p. 110) and an evasive displacement of the homoerotic encounter between Harker and the Count himself (p. 111). The monstrous sexuality embodied by Dracula (or the vampire in general) is thus both physically recognisable - in the full red lips that reveal sharp teeth and a threat of unnatural penetration - and intrinsically linked to his transgression of the norm, both in terms of physical appearance, and gender and sexual behaviour. ${ }^{4}$

Building on these theoretical inputs, this paper will take a look at the portrayal of villains in the Harry Potter series through the lens of gender, both in terms of physical appearance which, as we have

For a more in-depth discussion of this motif, see Creed, 2007.

4 For a discussion of the link between sexual transgression and the Gothic, see Palmer, 1999. 
shown, lends the villain instant recognisability, and in terms of the gender roles they fulfil or subvert. For reasons of space, the analysis will focus on the arch-villain of the story, Lord Voldemort, and the more complex and ambiguous character of Harry's teacher nemesis, Severus Snape. What follows first, however, is a closer look at the representation of villains and villainy in children's literature, and its peculiarities.

\section{THE BLACK HATS OF CHILDREN'S LITERATURE: A SHORT OVERVIEW}

In Avengers: Endgame (2019), in one of the Time Heist sequences, Scott Lang and Tony Stark time-travel back to 2012 and witness the agents of S.H.I.E.L.D. take Loki's staff, containing the Mind Stone, off the hands of Natasha Romanoff. Lang, who wasn't part of the original Avengers adventure they are now seeing, asks Stark who 'these guys' are. Stark tells him, "They're S.H.I.E.L.D. Well, actually, HYDRA. But we didn't know that yet." "Seriously?" replies Lang. "You didn't? I mean, they look like bad guys." While this is an expectedly corny joke befitting a superhero blockbuster, there is no denying that pop-culture villains do tend to have a rather conspicuous look. Or, as E. Quinn Fox puts it, "in traditional fantasy literature, evil is easy to identify. There is nothing subtle about Darth Vader or Lord Voldemort, a serpent or a dragon." (Heit, 2011, p. 132)

This is particularly true when it comes to children's literature, which often treads the line between "popular" and "literary". In terms of characterisation, children's literature often embraces the same patterns employed by the works of pop culture, such as comic books, fantasy stories, or highly stylised popular cinema like old school westerns and sci-fi pulp movies. Since children lack the necessary reading experience and practice, they are by default what narratology calls 'unsophisticated readers', and therefore rely less on subtlety and more on tropes to tell the difference between the white and black hats. Drawing on the work of theorists such as Edström and Nodelman, Maria Nikolajeva (2002, p. 28) points out that "the movement of the [Campbellian] monomyth is separation - initiation - return, which corresponds exactly to the 'basic plot' of children's fiction, identified as home - away - homecoming." It is 
no wonder then, that children's characterisation would follow that of mythology, since "all characters in children's fiction are a further development of the mythical hero. Like the mythical hero, the child character must depart from the ordinary situation in order for there to be a plot" (Nikolajeva, 2002, p. 28). The aforementioned examples of popular culture, like Marvel comics and films, also draw on the monomyth, which is where the similarities in character building between them and children's fiction come into play.

Although it is important to stress that not all children's literature necessarily reaches for a particular formula, it is true that more traditional stories, which do not question customary narrative rules but instead reiterate them, tend to follow the same patterns that genre fiction ${ }^{5}$ does, and thus they usually do not fail to hit all the required beats along the way. Hence, a work like Harry Potter, which, while exceptionally diverse in terms of genre, still follows the same basic structure of the Campbellian monomyth, consequently builds its story around the central conflict between the heroic protagonist and the villainous antagonist. Nikolajeva mentions that antagonists "are not absolutely indispensable in children's novels", but the majority of authors still choose to have them, as the "person-against-person conflict" is "the simplest and most clear-cut type of conflict in a narrative", adding that "most antagonists in fantasy and adventure novels for children are adults" (Nikolajeva, 2002, p. 123).

Going back to child audience as unsophisticated readers, we should try and define the characteristics of the villains who "look like bad guys". They do not always wear actual black hats, but their behaviour (if we look at mimetic characterisation) and narrative roles (if we turn to semiotic characterisation) tend to be such that we are left with little doubt as to their evilness. ${ }^{6}$ In his book on heroes and villains, Mike Alsford defines true villainy as a desire to dominate and impose one's will onto others, without any empathy whatsoever, concluding that "at the very heart of the notion of the villain is a refusal to submit to the social contract ... and a wilful

\footnotetext{
On the relationship between children's literature and genre, see Vujin, 2017.

6 We are here referring to the narratives that follow the monomyth pattern, as was established earlier in the text. Thus, we are dealing with the villain archetype, like Harry Potter's Lord Voldemort, and not merely with nuisances or rivals, like the trickster Cat in the Hat in Dr Seuss's eponymous work or the vices personified, like Veruca Salt, Violet Beauregarde, Augustus Gloop and Mike Teavee from Roald Dahl's Charlie and the Chocolate Factory, respectively.
} 
attempt at exploiting the fact that the rest of society chooses to be bound by it" (Alsford, 2006, p. 106). These are, as Cámara Arenas points out, "the traits that define the [psychoanalytical] psychotic type" - aggression, coldness, egocentrism, impulsiveness, lack of empathy, creativeness - and which paint "an accurate profile of many literary and filmic villains" (Fahraeus \& Yakali Çamoğlu, 2011, pp. 14-15).

Thus, the majority of children's fantasy antagonists can be classified as monstrous villains, characterised not only by their social monstrosity that expresses itself through disregard for the social contract and a lack of empathy, but also physical repulsiveness that could broadly be aligned with Freud's notion of The Uncanny. Typical representatives of the monstrous evil would be The Horned King from Disney's The Black Cauldron (1985), a living skeleton-like creature with gleaming eyes that "carries a touch of elderly frailty mixed with steely determination" (Davis 2015, p. 214), Emperor Sheev Palpatine from George Lucas's Star Wars saga ${ }^{7}$, and, of course, Lord Voldemort from J. K. Rowling's Harry Potter novels. These three characters are eerily similar, and their very appearance, in all its disfigured, hooded glory, seems to scream "villain".

Monstrous villains, however, are not the only stereotypical characters that inhabit books written for young audiences. Apart from them, there are, among many others, valiant boy heroes, charming female protagonists, spunky tomboys, wise wizards, ugly old hags, and last but not least, foppish male villains (Pugh, 2011, p. 105). One of the quintessential examples of this character archetype is, of course, Captain Hook from J. M. Barrie's Peter Pan. In her analysis of masculinity in Disney's feature films, Amy Davis reads Hook's “long hair, fancy coat, and large hat with its huge plume ... his long, pencil-thin moustache, and his set of 'Sunday hooks' ... as well as his melodramatic way of speaking and exaggerated actions" as proof that he is "a vain, silly man" (Davis, 2015, p. 191). We could, of course, counter that with another reading, and interpret Captain Hook - at least the animated Disney version - as, to borrow a phrase from Neil Gaiman and Terry Pratchett, "gayer than a tree full of monkeys on nitrous oxide" (Pratchett \& Gaiman, 2006, p. 169). In spite of this, as Davis points out, "Captain Hook, for all of

Even though Star Wars is a timeless classic enjoyed by all generations, Lucas has reiterated, time and again (most recently at the Fortieth Anniversary celebration held in 2017), that he originally conceived the first film (Episode IV: A New Hope, 1977) for twelve-year-olds. 
the theatricality of his characterisation, is nonetheless a genuine threat and persistent danger to those around him. In some ways, he is one of the most violent of the Disney villains, even if he is rarely successful in his attempts to cause harm" (Davis, 2015, p. 192). In Barrie's book, Hook is described as a handsome gentleman, an immaculately dressed and perfectly coiffed dandy who loves flowers and sweet music, in whose "dark nature there was a touch of the feminine, as in all the great pirates" (Barrie, 1995, p. 94). Clearly, there is something dangerous and villainous about a pirate in touch with his feminine side, though, to give Barrie credit, he makes certain to let his readers know that James Hook was not a "wholly unheroic figure" (159).

\section{HE WHO MUST NOT BE NAMED: TOM RIDDLE'S MONSTROUS VILLAINY}

While Captain Hook may have certain redeeming features, that is absolutely not the case with Tom Marvolo Riddle, the self-styled Lord Voldemort from the Harry Potter books. From the first mention (or rather, deliberate non-mention) of his name, both Harry and the reader are invited to be terrified of him, as Voldemort is repeatedly shown to be a monster who purposefully shed his humanity, and, as such, does not abide by natural human laws - Hagrid does not know "if he had enough human left in him to die" (PS 67). Throughout the seven books, we are faced with different incarnations of Voldemort - in Philosopher's Stone, he is a malevolent ghostly consciousness (popularly dubbed "Vapormort" in fan circles) possessing Professor Quirrell and manifesting as a Gothic double, a second face on the back of Quirrell's head; while in Chamber of Secrets, he is a memory-made-flesh of his handsome, sixteen-year-old self, known by his real name Tom Riddle. When he returns in Goblet of Fire, he at first occupies a monstrous, rudimentary body that lends the series a decidedly horror feel; soon after, Voldemort regains his pre-vaporisation body in a dark Gothic ritual, and both the reader and Harry stare "into the face that had haunted his nightmares for three years. Whiter than a skull, with wide, livid scarlet eyes, and a nose that was as flat as a snake's, with slits for nostrils... Lord Voldemort had risen again." (GoF 558) 
Voldemort's monstrosity is both social and physical - he is a psychopathic tyrant who finds humanity a weakness and seeks to destroy it both in himself and in others. Half-Blood Prince reveals the lengths to which he went in trying to secure immortality for himself - by murdering others and losing parts of his soul in the process. This is how he transformed from a handsome, human young man into a snake-like monster. His physical transformation is meant to show the corruption within, similar to the physical deformities that differentiate the Jedi hero Anakin Skywalker from his Sith Lord persona Darth Vader. Voldemort's physical monstrosity is there to easily mark him as the Other, the unnatural evil force that needs to be destroyed, but the repeated emphasis placed upon Tom Riddle's former good looks reminds the reader that one need not look like a monster to be classified as one. As Mary Pharr puts it,

Even when he was wholly human, Riddle was a sadist, the incipient Dark Lord who killed the girl doomed to become the ghost of Moaning Myrtle because it was expedient, probably entertaining - and because Riddle lacks empathy. He is a textbook sociopath. What makes him a serious epic antagonist is not just his power and intelligence; it is his willingness to do anything to anyone because he wants to do it. (Berndt \& Steveker, 2011, p. 13)

Voldemort is thus firmly established as the villain of the piece. In Harry's hero's journey, he functions as the antagonist, in its Gothic Double iteration - much stress is placed upon the similarities between Harry and him $^{8}$ - and he sometimes even fulfils the role of the negative father figure, another staple of the monomyth (most famously explored, without a doubt, in the literal father-son relationship of Luke Skywalker and Darth Vader). However, this is where things get more interesting: on the structural level, Voldemort may indeed function as the negative parental figure, but the

$8 \quad$ As Julia Boll succinctly puts it, "Voldemort as the shadow archetype embodies the dark reflection of Harry's own desires: equally an orphaned child, Voldemort never evolved but is left stuck in the mindset of having been abandoned. As it turns out, Harry also holds the shadow within himself, for Voldemort constitutes his unconscious self." (Berndt \& Steveker, 2011, p. 90) Taija Piippo also states that Voldemort is "an obvious manifestation of [Harry's] darker side, the heir of Slytherin, who possesses all those unwanted characteristics by which Harry fatalistically fears to have been tied down ... Tom as Voldemort completes Harry, having given him a set of traits that he has not acknowledged or even noticed in himself so far." (Heilman, 2009, p. 70) 
text makes certain to align him not with Harry's father, but with his mother.

When Voldemort first tries to kill Harry as a baby, it is Harry's mother's sacrifice that serves as a catalyst for everything that happens after that: throughout the series, we are reminded that magical words are performative utterances (the most obvious examples are all the spells, but there are also binding magical contracts, like putting one's name into the Goblet of Fire, or making an Unbreakable Vow); thus, when Lily Potter asks Voldemort to spare Harry and kill her instead, and he obliges, his subsequent attempted murder of Harry causes his curse to rebound upon him, vaporising him and detaching a bit of his soul that then latches itself onto Harry. This act links Voldemort not only to Harry, but also to Lily: both of them are now dead (or as good as dead, in Voldemort's case) as a result of Voldemort's attempt to kill Harry, and both of them have given something magical to Harry (protection, in her case, literal part of himself in his), transforming him into a different person and setting him on his heroic path. Harry is thus reborn as a son of Voldemort: by obliterating his mother, Voldemort perversely takes her place. ${ }^{9}$

Given that the Potter novels are children's books, it is understandable that sexuality is not at the forefront of the series, ${ }^{10}$ and their primary generic classification as adventure stories within a fantasy setting that follow the pattern of the heroic quest does not lend itself to much dwelling upon romance. Still, they are also novels for adolescents, set within the framework of boarding school story, so romance does tend to appear here and there - but it is usually explored in connection to the teenagers and young adults of the Wizarding World, not the adult figures, and certainly not Voldemort. Nevertheless, one cannot help but notice the peculiar desexualised masculinity of his character. His Death Eaters are shown to be a more or less homosocial group, with the notable exception of Bellatrix Lestrange (and, to a certain degree, her sister Narcissa Malfoy). He is described as unnaturally pale, tall, and thin, a malev-

9 In this sense, Voldemort reflects Victor Frankenstein's usurpation of the female prerogative of motherhood; the monster he creates, however is not Harry, but himself. It is also interesting to note that various theorists have interpreted the many representations of the monstrous female as a reflection of envy of women's reproductive power (see Ussher, 2006).

10 For a detailed reading of the "invisible sexuality" in children's literature, see Pugh, 2011. 
olent figure without any of the robustness usually perceived as a masculine trait. His lack of a nose and fondness for snakes certainly raise a Freudian eyebrow, as does his tendency to twirl his (and on one occasion, Harry's) wand ${ }^{11}$ between his "long, pale fingers", and much is made of his "high, cold voice" (compare this to Darth Vader's imposing masculinity and his famous basso profundo). His association with the Basilisk in particular, the giant serpent that appears in Chamber of Secrets, petrifies its victims and is eventually penetrated by a valiant sword-wielding male character, can be read as a reiteration of the Medusa motif, which places Voldemort within the tradition of the monstrous feminine. His rejection of his father (achieved both by the literal murder of his father and his paternal grandparents, and by the metaphorical shedding of his patronymic Tom Riddle) and his claim of his matrilineal slytherin heritage point to the embrace of his feminine side - this is where his monstrosity truly stems from, the books seem to say. And yet, in a curious reversal, he is "reborn by means of an all-male trio of donors who with some reluctance provide their blood, flesh and bone, while the only feminine element in this rebirth is the cauldron as womb" (Mills, in Heilman, 2009, p. 253). Voldemort's masculinity is questioned, regained, and undermined over and over again, turning him into an uncanny, androgynous figure. One notable example is his fusion with Harry; as Susanne Gruss points out, this connection "also strengthens Harry's femininity: his psyche is penetrated by the stronger Voldemort" (Berndt \& Steveker, 2011, p. 49); it also underlies his transgressive nature much in the same way as with Dracula and Harker. On the other hand, later on, when trying to fully possess Harry, Voldemort feels such unbearable pain that he does not dare to do it again: his attempt at penetration is thus unsuccessful and he is once again metaphorically unmanned.

Not all critics, however, agree with this sentiment. Karley Adney (in Berndt \& Steveker, 2011, pp. 177-191), for instance, sees all the men who have the greatest influence on Harry - Dumbledore, Snape and Voldemort - as traditionally masculine. Snape's brand of masculinity will be explored in greater detail in the next section of this paper, while Dumbledore's is outside our scope, since he is not a villainous presence in the novels, though it bears pointing out

11 A nice illustration of the obvious phallic symbolism of the wand can be observed when Bellatrix says to Lucius, "You lost your authority when you lost your wand, Lucius!" (DH 373), or when the now powerless Voldemort is unable to use the Elder Wand against Harry in the final showdown. 
that Adney reads the relationship between the canonically gay Dumbledore and Gellert Grindelwald only as a close friendship. Adney bases her reading on the BSRI (Bem Sex-Role Inventory), established by the psychologist Sandra Bem in the 1970s, whereby traits such as independence, willingness to defend one's beliefs, individuality, or aggressiveness are defined as masculine, and concepts such as empathy or loyalty are seen as feminine. In this reading, it is no wonder that Voldemort is seen as overwhelmingly masculine. We, however, feel that such a reading is rather too restrictive. Voldemort is without a doubt a patriarchal villain - as Sara Martin points out, "the hierarchical distribution of patriarchal power generates the individual villainy of the men who, feeling entitled to greater share of power than they actually have, vent out their frustration on others" (Fahraeus \& Yakali Çamoğlu, 2011, p. 42) - but patriarchy and masculinity are not synonymous.

Another psychological reading, which we feel is more accurate, is that of Ken Rothman, who sees Voldemort as "a pure instantiation of Thanatos", as "he has no interest in food, drink, sex, affiliation, or constructive achievement", but shows only "a death-anddestruction-loving will to power and thirst for vengeance against anyone believed to have thwarted him." (Heit, 2011, p. 204) In this regard, Voldemort leaves behind his humanity and gives himself completely to his desire for destruction. Though strangely "unsexed" and demasculinised, he still reinforces patriarchy, by seeking, like Emperor Palpatine, "unlimited power" and setting himself as the de facto ruler of the British Wizarding World. It can therefore be concluded that Voldemort is a prime example of monstrous villainy, with a garnish of queer-coding.

\section{SUBVERTING THE STEREOTYPES: SEVERUS SNAPE}

Severus Snape, at first the Potions Master at Hogwarts, later the DADA teacher, and finally, the Headmaster, is easily the most interesting and well-executed character in the Potter books. As the quintessential contagonist, he occupies one of the central narrative roles in the series, and his structural position within the narrative shifts from antagonist to shadow to dark mentor to anti-hero. Julia Boll points out that he primarily embodies the archetype of the shapeshifter, going on to define this role as the one that "brings out the hero's weaker sides and encourages him to face them ... True to 
his archetype, Snape's loyalty and sincerity are often in question." (Berndt \& Steveker, 2011, p. 90) During the publication of the books, the majority of fandom discussions centred around Snape and whose side he was really on, and his allegiance to Harry was only confirmed in the final book of the series.

From the first moment he is introduced, Snape is presented in a villainous way and strongly associated with the colour black: he is dressed in all black, has "greasy black hair, a hooked nose and sallow skin" (PS 138), his eyes are "black like Hagrid's, but they had none of Hagrid's warmth. They were cold and empty and made you think of dark tunnels" (PS 150). His classroom and office are in the dungeons, and he is often compared to a "large and malevolent bat" (CoS 144). He gives no qualms about disliking Harry, he is a cruel and sadistic teacher, and he is clearly presented as a dangerous individual, a typical black hat. And yet, every time he is suspected of being the bad guy (which is pretty much all the time), it turns out that he is not. Megan L. Birch states that Snape is "complex and multifaceted", but also "an evil, malevolent teacher with an inexcusable fear-induced pedagogy." (Heilman, 2009, p. 112) On the structural level, Snape functions as Rowling's favourite red herring, and Harry's dislike, even hatred of him, obviously colours the reader's perception of the character, since the narrative is focalised through Harry. Thus, Rowling ensures that the final reveal - that Snape gave his life to protect Harry out of his loyalty to and love for his dead mother Lily - comes as a surprise for her young audience.

Snape's position within the narrative often mirrors that of other characters, most often the other three central characters in the series - Dumbledore, Voldemort, and Harry himself. Similarities between Harry and Voldemort can be extended to encompass Snape as well: just like the other two, he is a profoundly damaged individual, a dark-haired Halfblood who grew up in a loveless environment and came to regard Hogwarts as his one true home. While Dumbledore occupies the "wise mentor" role in Harry's hero's journey, Snape can be seen as a dark mentor figure, teaching Harry by way of counterexample and mostly outside of the excepted social sphere - notable examples include him yelling instructions at Harry even while he is allegedly duelling him ("Blocked again, and again, and again until you learn to keep your mouth shut and your mind closed, Potter!" - HBP 562) and his old potions book serving almost as a tutor and friend to Harry during his sixth year at Hogwarts. And, of course, one must not forget that it was Snape who 
taught Harry his "trademark" disarming spell, which is how Harry defeats not only numerous "little bads" along the way, but also the Big Bad himself, Lord Voldemort.

Befitting his ambiguous role in the story, Snape is also the most liminal character in the series. As Peter Appelbaum notices, Snape is "the only Hogwarts teacher who maintains links to the real world", he is "on the edge" and can seemingly "go either way", his teachings include both the "standard part of the curriculum" and "skills for the outside world" (Heilman, 2009, p. 92), and last but not least, he is "the only character to win the trust of both Dumbledore and Voldemort, both the Order of the Phoenix and the Death Eaters" (Heilman, 2009, p. 95). His liminality seems to spread to his gender presentation as well, symbolically shown in his skillset, as demonstrated by the speech he gives at the beginning of Harry's first ever Potions lesson:

You are here to learn the subtle science and exact art of potion-making. ... As there is little foolish wand-waving here, many of you will hardly believe this is magic. I don't expect you will really understand the beauty of the softly simmering cauldron with its shimmering fumes, the delicate power of liquids that creep through human veins, bewitching the mind, ensnaring the senses... I can teach you how to bottle fame, brew glory, even stopper death - if you aren't as big a bunch of dunderheads as I usually have to teach. (PS 150)

Once again, Freudian symbolism is overwhelming: Snape denigrates wand-waving as "foolish" (though, as we will find out, he is one of the most skilled "wand-wavers" in the series), and instead focuses on the cauldron, using the words "soft", "shimmering" and "delicate" to describe it. The rejection of the phallic this time comes with the embrace of the yonic, and Snape is aligned with the historic representation of the witch (stirring a cauldron), not of the wizard (using a wand or a staff).

Even though, according to Adney, Snape embodies the very masculine qualities of aggressiveness and the desire to defend his own beliefs (Berndt \& Steveker, 2011, p. 185), he is also strongly associated with the feminine quality of loyalty, through his unwavering devotion to a dead beloved and, by extension, to her son. Just like Voldemort, Snape too can be seen as a negative parental figure, and even though he is often compared to Harry's father James and his substitute father figure, his godfather Sirius, he is, again, just like Voldemort, aligned with Harry's mother Lily. ${ }^{12}$ In the last book, we find out that Snape and Lily met as children and grew up together, 
became best friends and had a falling out, with Lily then moving on and marrying James Potter, and Snape becoming a Death Eater who remained in love with Lily even after her death. As Nikolajeva explains,

His devotion to the son of his dead beloved is so immense that he is prepared to bear a mark of the Dark Arts on his body, to live a life as a double spy, a life of lies and pretence, of contempt and hate from fellow teachers as well as students, including the object of his concerns. While Harry's life is full of risk and danger, yet with high stakes to win, Snape's is utter misery and no reward. Thus the seven-volume epic can be viewed as a distressing story of a pathetic man who longs for the son he has never had. (Heilman, 2009, pp. 239-240)

This maternal connection is best exemplified though Snape's Patronus, which takes the form of a doe - a distinctly feminine shape, described as "beautiful" and "long-lashed" - which he shares with Lily. Compared both to James' Animagus form of a stag, and Harry's own stag Patronus, Snape's doe puts him firmly into the role of a mother figure and aligns him with the feminine.

Snape's "good" side is thus connected with the feminine through his maternal role in Harry's life. What about his "bad" side? Once again, his sexuality is downplayed, just like that of Voldemort and almost every other adult in the series (though Freudians would probably have a field day with the emphasis that is placed over and over again on his overlarge nose ${ }^{13}$ ). Still, there is a memorable scene that puts him in drag and strongly underlines his villainous nature, thus combining the two in the readers' minds. When confronted by a Boggart, the creature that takes the form of whatever frightens one the most, one must think of a way to make it look ridiculous, because laughter destroys fear. Harry's schoolmate Neville Longbottom is deathly afraid of Professor Snape, who relentlessly bullies him. The scene unfolds as follows:

'When the Boggart bursts out of this wardrobe, Neville, and sees you, it will assume the form of Professor Snape,' said Lupin. 'And you will raise your wand - thus - and cry "Riddikulus" - and concentrate hard

12 Another feminine feature Snape shares with Voldemort is the fact that he, too, reaches for his matrilineal heritage, dubbing himself the Half-Blood Prince, after his mother's maiden name.

13 Snape's nose also echoes the hooked nose of the witch. Interestingly enough, Campbell views the witch's long fingers and hooked nose as phallic symbols (Campbell, 1960, p. 73), which further testifies to her ambiguous, liminal position - much like Snape's. 
on your grandmother's clothes. If all goes well, Professor Boggart Snape will be forced into that vulture-topped hat, that green dress, that big red handbag.'

... The Wardrobe burst open. Hook-nosed and menacing, Professor Snape stepped out, his eyes flashing on Neville.

Neville backed away, his wand up, mouthing wordlessly. Snape was bearing down upon him, reaching inside his robes.

'R-r-riddikulus!' squeaked Neville.

There was a noise like a whip-crack. Snape stumbled; he was wearing a long, lace-trimmed dress and a towering hat topped with a moth-eaten vulture, and swinging a huge crimson handbag from his hand.

There was a roar of laughter, the Boggart paused, confused (PoA 102104)

At first glance, this particular drag performance might appear as a subversion of the traditional association between femininity and monstrosity: by donning female clothes, Snape is divested of his potential to inspire dread (as is the Boggart) and no longer appears threatening. However, since the mechanism of the spell relies on the transformation of the source of one's fear into something ridiculous, the resolution of the scene can be read as both misogynist and transphobic: the feminine is relegated from the realm of the monstrous to the realm of the laughable. It also calls to mind the history of forcing slaves to wear women's clothes in order to symbolically emasculate them and make them more submissive. Finally, one must also note that Neville's grandmother, whose clothes Snape is wearing in the scene, is portrayed as quite a daunting figure herself (Neville is quick to say that he does not want his Boggart to turn into her either), and one might think that the sight of Snape and his grandmother fused together may well inspire even greater dread (however well-intentioned she is revealed to be later on). In this sense, Snape's villainy is here diluted by redefining him, at least briefly, within the more instantly recognisable category of the monstrous feminine (the strict and evil mother figure), thus removing the ambiguity of his character and transforming him into a monster that is at least familiar and can be reckoned with. 
CONCLUSION: ORDER RESTORED
The idea of the monstrous feminine is as ubiquitous as it is powerful. In children's fiction in particular, especially in a narrative that revolves around the conflict between good and evil and follows the pattern of the heroic quest, it is inevitable that this motif should appear in various forms. As we have seen, even though the antagonist and the contagonist of the series are both male, they are repeatedly portrayed in a way that destabilises their gender identity and aligns them with the tradition of using the female or the homosexual as the archetype of evil. We have shown that the feminine coding of their villainy serves a double purpose - to affirm it by evoking the horrors of the monstrous feminine, or to emasculate them and make them appear weak and ineffectual. By the end of the series, both characters are killed off, as befits a feminine (or feminine-coded) monster.

Even though characters are, as we have seen, mostly quite desexualised, in line with the target audience, if the end point of the Campbellian monomyth is return, it would seem that the return in Harry Potter spells out reaffirmation of the heteronormative order. Because he is not universally evil, but a complex character whose motivation stems from loyalty rather than pure desire to control, the feminine coding of Snape's character is potentially more subversive and he is thus killed off first. Then, in the final showdown, the threat of fluid, non-conforming gender is fully defeated and successfully removed, as in Dracula, and the narrative ends in a triumph of heteronormativity: we see Harry married to Ginny, with three children, at King's Cross, waiting for his son Albus to board the train to Hogwarts, as they are accompanied by another heterosexual couple, Hermione and Ron. In other words, by the end of the series, the queer threat is dispelled, the hero has secured an heir (two, in fact), and heteronormativity can once again breathe a sigh of relief.

Alsford, M. (2006). Heroes and Villains. Waco: Baylor University Press.

Barrie, J. M. (1995). Peter Pan. London: Penguin.

Berndt, K. \& Steveker, L. (Eds.) (2011). Heroism in the Harry Potter Series. Farnham: Ashgate.

Campbell, J. (1960). The Masks of God: Primitive Mythology. London: Secker \& Warburg.

Craft, C. (1984). 'Kiss Me with Those Red Lips': Gender and Inversion in Bram Stoker's Dracula. Representations, 8, 107-133. doi:10.2307/2928560 
Creed, B. (1986). Horror and the Monstrous-Feminine: An Imaginary Abjection. Screen, 27 (1), 44-71. doi:10.1093/screen/27.1.44

Creed, B. (2007). The Monstrous-Feminine: Film, Feminism, Psychoanalysis. London and New York: Routledge.

Davis, A. M. (2015). Handsome Heroes and Vile Villains: Men in Disney's Feature Animation. Bloomington: John Libbey Publishing.

Fahraeus, A. \& Yakali Çamoğlu, D. (Eds.) (2011). Villains and Villainy: Embodiments of Evil in Literature, Popular culture and Media. Amsterdam-New York: Rodopi.

Heilman, E. (Ed.). (2009). Critical Perspectives on Harry Potter (2 ${ }^{\text {nd }}$ edition). New York-London: Routledge.

Heit, J. (Ed.). (2011). Vader, Voldemort and Other Villains: Essays on Evil in Popular Media. Jefferson: McFarland \& Company, Inc. Publishers.

Nikolajeva, M. (2002). The Rhetoric of Character in Children's Literature. Lanham: Scarecrow Press, Inc.

Palmer, P. (1999). Lesbian Gothic: Transgressive Fictions. London: Cassell/Continuum.

Pratchett, T. \& Gaiman, N. (2006). Good Omens. Reading: Corgi Books.

Pugh, T. (2011). Innocence, Heterosexuality, and the Queerness of Children's Literature. New York-London: Routledge.

Rowling, J. K. (2000). Harry Potter and the Philosopher's Stone. London: Bloomsbury.

Rowling, J. K. (2002). Harry Potter and the Chamber of Secrets. London: Bloomsbury.

Rowling, J. K. (2000). Harry Potter and the Prisoner of Azkaban. London: Bloomsbury.

Rowling, J. K. (2000). Harry Potter and the Goblet of Fire. London: Bloomsbury.

Rowling, J. K. (2004). Harry Potter and the Order of the Phoenix. London: Bloomsbury.

Rowling, J. K. (2005). Harry Potter and the Half-Blood Prince. London: Bloomsbury.

Rowling, J. K. (2007). Harry Potter and the Deathly Hallows. London: Bloomsbury. Shakespeare, W. (1996). The Complete Works. Ware: Wordsworth Editions.

Shildcrout, J. (2014). Murder Most Queer: The Homicidal Homosexual in the American Theater. Ann Arbour: The University of Michigan Press.

Stoker, B. (1983). Dracula. Oxford: OUP.

Ussher. J. (2006). Managing the Monstrous Feminine: Regulating the Reproductive Body. London and New York: Routledge. 
Vujin, B. (2017). Čarobnjaci i leptiri: engleska i srpska fantastična proza za decu. U: Gordić Petković, V. i Paunović, Z. (ur.). Žanrovska ukrštanja srpske i anglofone književnosti (pp. 131-145). Novi Sad: Matica srpska.

БОЈАНА С. ВУЈИН

ВИКТОРИЈА Е. КРОМБХОЛЦ

УНИВЕРЗИТЕТ У НОВОМ САДУ

ФИЛОЗОФСКИ ФАКУЛТЕТ

ОДСЕК ЗА АНГЛИСТИКУ

РЕЗИМЕ МРАЧНИ ГОСПОДАР ВИСОКОГ ГЛАСА И БАУК У ХАљИНИ:
ФЕМИНИЗАЦИЈА ЗЛИКОВЦА У РОМАНИМА О ХАРИЈУ ПОТЕРУ

У књижевности и на филму, нарочито у жанровским делима, главни зликовац често је лако препознатљив, јер његов изглед већ на први поглед изазива језу својом ружноћом, деформитетом или свеопштом нељудском појавом или макар хладним погледом који открива његову изопачену природу. Слична правила важе и у дечјој књижевности, будући да млађа публика услед недостатка читалачког искуства теже уочава нијансе у карактеризацији, а лакше препознаје већ познате обрасце и архетипске ликове. Поред физичког изгледа, негативци често одступају од друштвено прихватљивих (патријархалних, хетеронормативних) оквира родног или сексуалног идентита, пре свега својим изгледом, али и понашањем или улогама које им структурно припадају, што се може довести у везу са схватањем женског као чудовишног и стравичног. Како показује теоретичарка филма Барбара Крид (Creed), овакве представе женског могу се наћи у ликовима из античког мита, све до савремених примера из популарне културе, као што је серијал Осми йуйник. У основи ових представа лежи доживљај женске сексуалности као неспознатљиво другачије и стога монструозне, те ужас, али и завист, који изазива женска способност репродукције. Стога је феминизација мушких ликова врло једноставан начин да се они прикажу као подједнако монструозни, неприродни и зли. Полазећи од ових теоријских поставки, рад анализира начине на који су у серијалу Хари Поиеер Џ. К. Роулинг представљени Лорд Волдемор, главни Харијев непријатељ и зликовац који прети да уништи читав чаробњачки свет, те Северус Снејп, зли наставник који кињи Ха-

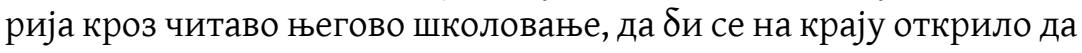


је у борби између добра и зла он ипак све време на страни добра, уз огромну личну жртву. Понуђена дискусија првенствено показује како се овим ликовима приписују женске особине или намећу женске улоге не би ли се дочарала или нагласила њихова чудовишност и исквареност; међутим, пример Северуса Снејпа доказ је да оваква карактеризација у исти мах може да допринесе комплексности ликова, те да послужи као знак њихове људскости.

КључнЕ РЕчи: дечја књижевност; зликовац; род; монструозно-женско; Хари Потер.

Овај чланак је објављен и дистрибуира се под лиценцом Creative Commons Ауторство-Некомерцијално Међународна 4.0 (CC BY-NC 4.0 |

https://creativecommons.org/licenses/by-nc/4.0/).

This paper is published and distributed under the terms and conditions of the Creative Commons Attribution-NonCommercial International 4.0 licence (CC BY-NC 4.0 | https://creativecommons.org/licenses/by-nc/4.0/). 